\title{
CLINICOPATHOLOGICAL STUDY OF SKIN TUMOURS IN WESTERN RAJASTHAN
}

\author{
Ajit Singh Beniwal1, Surendra Prakash Vyas², Dharmveer Sihag ${ }^{3}$ \\ ${ }^{1}$ Senior Demonstrator, Department of Pathology, S.P. Medical College, Bikaner, Rajasthan, India. \\ 2Professor, Department of Pathology, S.P. Medical College, Bikaner, Rajasthan, India. \\ 3Medical Officer, Department of Pathology, S.P. Medical College, Bikaner, Rajasthan, India.
}

\section{BACKGROUND}

\section{ABSTRACT}

Present study was conducted to evaluate the clinicopathological profile of skin tumours Bikaner, Rajasthan.

\section{MATERIALS AND METHODS}

Present study consisted of analysis of tumours of skin received in the histopathology section of department of pathology over a period of 4 years that is from year 2014 to 2017. The material comprised of biopsies and excision specimens. Inclusion criteria: All benign and malignant tumours of skin were included. Exclusion Criteria: All non-neoplastic lesions and tumour like lesions of skin were excluded.

\section{RESULTS}

In our study, males outnumbered females and most common clinical features were swelling (87.6\%) which was the most common clinical feature followed by papule (24.7\%), pigmented lesions (13.8\%), cyst (13.8) and ulcer (12.8\%). Most common benign skin lesions were seborrheic keratosis, warts and haemangioma. And, most common malignant skin tumour was squamous cell carcinoma followed by basal cell carcinoma.

\section{CONCLUSION}

Skin malignancies are often associated with greater morbidity, necessitating increased efforts to assess risk factors in individuals, to encourage periodic self-examination and professional evaluation of skin and to optimize strategies for earlier diagnosis and treatment.

\section{KEY WORDS}

Benign, Malignant, Clinical.

HOW TO CITE THIS ARTICLE: Beniwal AS, Vyas SP, Sihag D. Clinicopathological study of skin tumours in Western Rajasthan. J. Evolution Med. Dent. Sci. 2019;8(07):407-411, DOI: 10.14260/jemds/2019/90

\section{BACKGROUND}

The skin is the largest organ in the body. It has complicated structure and serves many functions.(1) A wide variety of hyperplastic growths and tumours, both benign and malignant are encountered in the clinical practice. The ability to properly diagnose and treat the tumours is a vital skill for all clinicians. Any lesion, for which the diagnosis is uncertain, based on the history and clinical examination should be biopsied for histopathological examination to rule out malignancy.(2)

The most prevalent forms of skin cancer are basal cell carcinoma (representing $80 \%$ of all skin cancers), squamous cell carcinoma (10\%), and melanoma (8\%). Currently, the incidence of skin cancer is on the rise, $(3,4)$ and this increase is due primarily to increased sun exposure. The prognosis for skin cancer depends on the type of tumour and the stage of the disease. Although basal cell carcinomas rarely metastasise, as a result of their growth they can cause serious damage to the surrounding tissue if not treated in time.

'Financial or Other Competing Interest': None.

Submission 23-12-2018, Peer Review 01-02-2019,

Acceptance 07-02-2019, Published 18-02-2019.

Corresponding Author:

Dr. Ajit Singh Beniwal,

C/131/3/26, CAD Quarters,

Jai Narayan Vyas Colony,

Bikaner-334003,

Rajasthan, India.

E-mail: nonee2010@rediffmail.com

DOI: $10.14260 /$ jemds $/ 2019 / 90$
This risk of local tissue damage also applies to squamous cell carcinomas; in addition, approximately $1-4 \%$ of these tumours metastasise. The risk of metastasis depends on the size and location of the tumour. Squamous cell carcinoma has a relative 5-year survival rate of $92-95 \% .4$ Melanoma has a relative 5 -year survival rate of $87 \% 6$, but this rate varies widely depending on the stage of the tumour. For example, patients with stage IV melanoma have a 5-year survival rate of only $15-20 \%$.(5) Therefore, diagnosing and treating skin cancer early is essential for preventing damage to the surrounding tissue and improving survival.

While the incidence of skin cancer is increasing,(3,4) campaigns are being used to increase public awareness of this epidemic.(6) It can therefore be anticipated that the number of patients consulting a general practitioner (GP) for a potentially malignant lesion of the skin will rise. It is the task of the GP to diagnose skin malignancies as early as possible while at the same time preventing unnecessary excisions and referrals to secondary care. This is particularly the case in countries where the GP has a gatekeeper role. For the evaluation and management of potentially malignant skin lesions, the GP has several strategies varying from taking medical history and physical examination, teleconsulting a dermatologist, excision or referral. Although several, old, studies have reported on the sensitivity and specificity of specific skin lesions, (7) to the best of our knowledge, there are no studies on the diagnostic accuracy of GPs for the entire spectrum of potentially malignant skin lesions as presented in general practice. Further studies about late or missed diagnosis of skin malignancies by the GP are lacking. 
Malignant skin lesions have become increasingly prevalent over the past several years. In United States, approximately 5.4 million cases of non-melanoma skin cancers are treated in 2012.(8) Skin cancer account for more than $40 \%$ of all malignancies. Majority of skin cancers are basal cell carcinoma (BCC), squamous cell carcinoma (SCC) and melanoma which account for more than $95 \%$ of total skin malignancies.(8) Skin cancer is the 5th leading cost of deaths among all the cancers in the world.(9)

In India, malignant skin tumours (cancers) constitute about $1-2 \%$ of all cancers. Various cancer registries in India reported cumulative incidence of skin cancer varying from 0.5 to 2 per 100000 population.(10) Despite growing public awareness of harmful effects of sun exposure, incidence continues to rise. Non-melanoma Skin Cancers (NMSC) are associated with substantial morbidity, including loss of function and disfigurement, and their treatment is costly. Early diagnosis can reduce morbidity and cost. There is definite role of pathologist in the management of tumours. But due to diversity of these tumours, there can be confusion regarding nomenclature of these tumours.(11) As a result, the study of skin tumours is perhaps more interesting and challenging than any other tumours.

The aim of this study as to assess the clinicopathological profile of malignant skin lesions in the patient's presenting in S.P. Medical College and PBM hospital, Bikaner.

\section{MATERIALS AND METHODS}

The present descriptive study consisted of analysis of tumours of skin received in the histopathology section of department of pathology over a period of 4 years that is from year 2014 to 2017. The material comprised of biopsies and excision specimens.

\section{Inclusion Criteria}

All benign and malignant tumours of skin were included.

\section{Exclusion Criteria}

Haemorrhagic specimen and autolyzed and necrotic specimen were excluded. All tumours and tumour like lesions of skin of genitalia were excluded. The tumours were classified according to World Health Organization classification of skin.

A detailed clinical data including age, sex, anatomical location, clinical diagnosis, haematological profile, radiography and surgical diagnosis were collected using standard proforma. The macroscopic findings like size, shape, colour, macroscopic extension and consistency of the samples were recorded.

The specimens were received in $10 \%$ formalin and fixed for 12 to 24 hours. The gross findings were noted. Specimens measuring $3 \mathrm{~mm}$ or less were submitted. Specimens measuring 4-6 mm were bisected and submitted totally. Specimens measuring $7 \mathrm{~mm}$ or more were cut into slices measuring 2-3 $\mathrm{mm}$ and all were submitted for processing. For wide local excision specimen, 2-4 sections from the tumour and 4 or more sections from the surgical margins including deep surgical margin were taken. Tissue was further processed and then embedded in paraffin wax. Three to fivemicron thick sections were cut on a rotary microtome. All the sections were stained by haematoxylin and eosin. The clinical information regarding age, sex, location of the tumour and any other special clinical features were obtained from specimen requisition form or from patient's case records.

\section{RESULTS}

Present study was conducted in Oncology department in PBM hospital, Bikaner. Total 312 cases of benign and malignant skin tumours were taken in four years from 2014 to 2017.

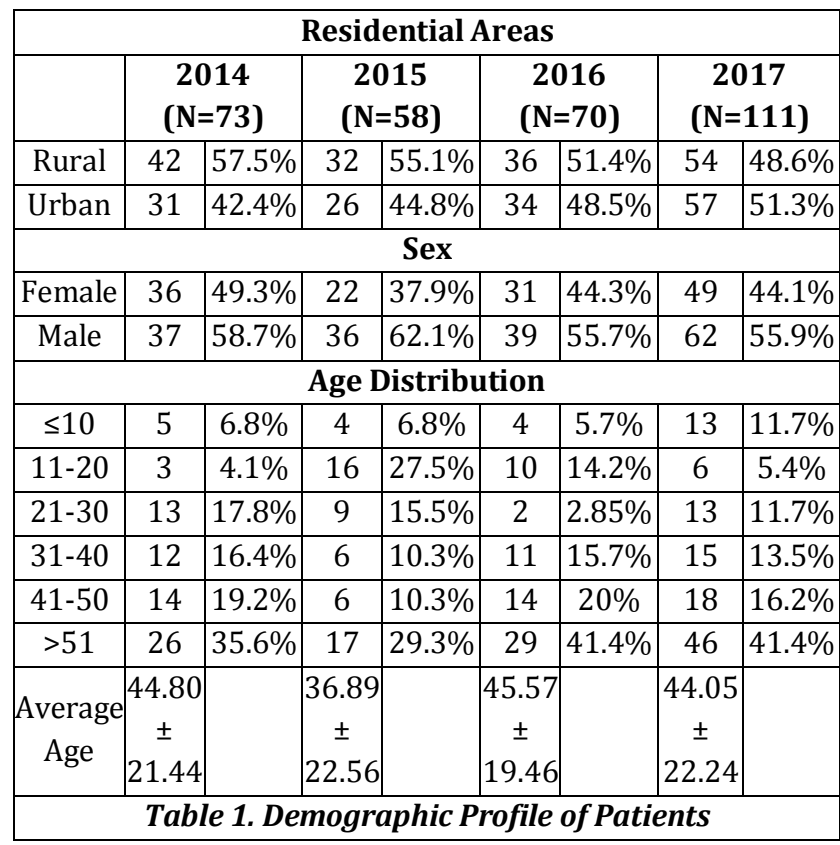

Table 1 shows the demographic profile of patients. Here, mean age of patients in year 2014, 2015, 2016 and in 2017 were $44.80 \pm 21.44,36.89 \pm 22.56,45.57 \pm 19.46$ and $44.05 \pm$ 22.24 repectivley. Most common age group was greater than 51 years group. In year $201457.7 \%$ patients from rural and $42.4 \%$ from urban area. Similarly, $55.1 \%$ from urban and 44.85 from rural in year 2015, 51.4\% from urban and $48.5 \%$ from rural in year 2016 and $48.6 \%$ from urban and 51.3 from rural in year 2017. In our study male preponderance was shown in every year as compared to females.

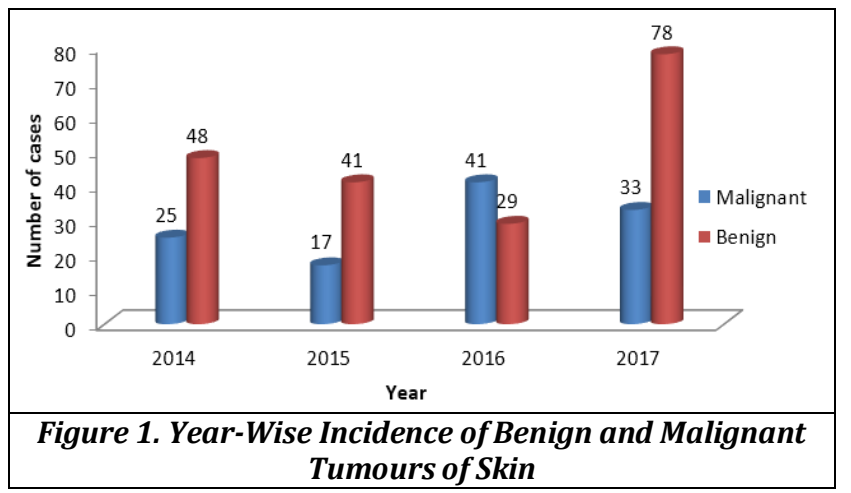

Figure 1 shows the year wise incidence benign and malignant tumours. Benign skin lesions were common in or study as compared to malignant. There were more malignant skin lesions in year 2016 as compared to other years. 


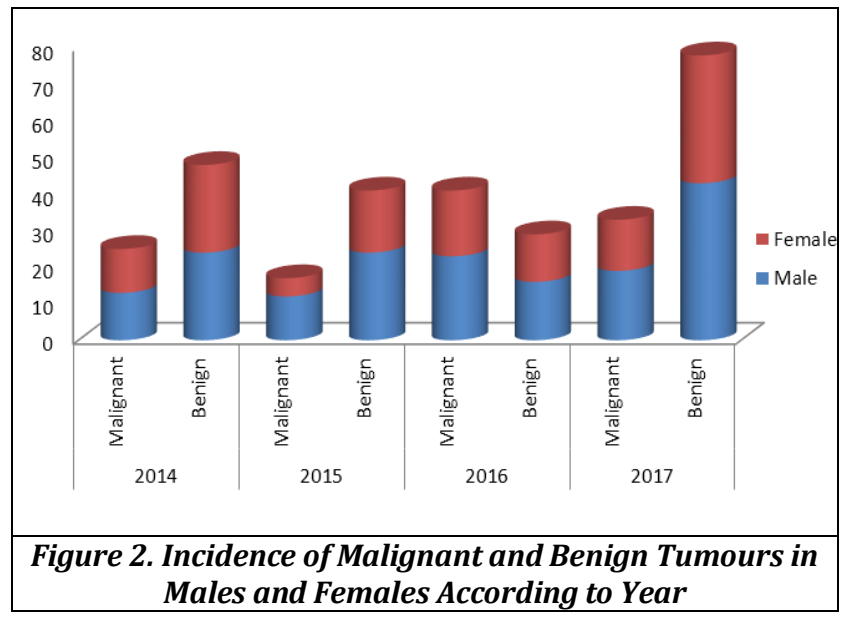

Figure 2 shows the incidences of benign and malignant skin lesion in male and females in different years. Here the skin related lesions were found more in males as compared to females.

\begin{tabular}{|c|c|c|}
\hline Clinical features & Number & Percentage \\
\hline Cyst & 29 & $13.8 \%$ \\
\hline Exophytic Papule & 19 & $9.04 \%$ \\
\hline Moles & 3 & $1.42 \%$ \\
\hline
\end{tabular}

\begin{tabular}{|c|c|c|}
\hline Nodulated & 20 & $9.52 \%$ \\
\hline Nodule with Cyst & 19 & $9.04 \%$ \\
\hline Papule & 52 & $24.7 \%$ \\
\hline Pigmented Lesions & 29 & $13.8 \%$ \\
\hline Plaque & 2 & $0.95 \%$ \\
\hline Polypoidal & 6 & $2.85 \%$ \\
\hline Reddishness & 18 & $8.57 \%$ \\
\hline Sacrococcygeal Mass & 1 & $0.47 \%$ \\
\hline Scapula Nodule & 1 & $0.47 \%$ \\
\hline Swelling & 184 & $87.6 \%$ \\
\hline Ulcer & 27 & $12.8 \%$ \\
\hline \multicolumn{2}{|c}{ Table 2. Clinical Features } \\
\hline
\end{tabular}

Table 2 shows the clinical features present in patients. Out of total patients swelling (87.6\%) were the most common clinical feature followed by papule $(24.7 \%)$, pigmented lesions (13.8\%), cyst (13.8) and ulcer (12.8\%). Other clinical features found were Exophytic papule (9.04\%), Moles (1.42\%), Nodulated (9.52\%), Nodule with Cyst (9.04\%), Plaque (0.95\%), Polypoidal (2.855), Reddishness (8.57\%), Sacrococcygeal Mass $(0.47 \%)$ and scapula nodule $(0.47 \%)$ Table: 3 incidences on different type of benign and malignant skin tumour in different years. Most common benign skin lesions were Seborrheic Keratosis, warts and Haemangioma. And, most common malignant skin tumour squamous cell carcinoma followed by basal cell carcinoma.

\begin{tabular}{|c|c|c|c|c|c|c|c|c|c|}
\hline \multirow{2}{*}{$\begin{array}{c}\text { Benign } \\
\text { Tumours }\end{array}$} & \multicolumn{4}{|c|}{ Number of Patients Year Wise } & \multirow{2}{*}{$\begin{array}{l}\text { Malignant } \\
\text { Tumours }\end{array}$} & \multicolumn{4}{|c|}{ Number of Patients Year Wise } \\
\hline & 2017 & 2016 & 2015 & 2014 & & 2017 & 2016 & 2015 & 2014 \\
\hline Basal Cell Adenoma & 1 & - & - & - & Basal Cell Carcinoma & 12 & 16 & 4 & 7 \\
\hline Compound Naevus & 1 & 1 & 1 & 4 & DFSP & 2 & - & - & - \\
\hline Corn & 4 & 1 & 1 & 1 & $\begin{array}{l}\text { GCT Lesion of Tendon } \\
\text { Sheath }\end{array}$ & 1 & - & - & - \\
\hline Cylindroma & 1 & 1 & - & 1 & Keratoacanthoma & 2 & 5 & 1 & - \\
\hline Dermal Naevus & 2 & - & - & - & Melanoma & 1 & - & - & - \\
\hline Dermatofibroma & 2 & - & 2 & 2 & Meibomian Gland ca & 1 & - & - & - \\
\hline Dermoid Cyst & 1 & - & - & - & SCC & 13 & 20 & 12 & 15 \\
\hline Eccrine Acrospiroma & 4 & 2 & 3 & 3 & Poorly Differentiated ca & 1 & - & - & - \\
\hline Eccrine Poroma & 1 & 2 & - & - & Basal Cell Epithelioma & - & - & - & 2 \\
\hline Eccrine Spiradenoma & 5 & 1 & 3 & 1 & Benign Tumours & 2017 & 2016 & 2015 & 2014 \\
\hline Eosinophilic Granuloma & 1 & - & - & - & Neurofibroma & - & - & 8 & 16 \\
\hline Fibroepithelial Polyp & 1 & - & - & - & $\begin{array}{c}\text { Pseudoepitheliomatous } \\
\text { Hyperplasia }\end{array}$ & - & - & 4 & - \\
\hline GCT Lesion of Tendon Sheath & 4 & - & - & - & Schwannoma & - & - & 2 & - \\
\hline Haemangioma & 7 & 1 & 7 & 7 & Pyogenic Granuloma & - & - & 1 & - \\
\hline Haemangiopericytoma & 1 & - & - & - & Cavernous Haemangioma & - & - & 1 & - \\
\hline Hidradenoma Papilliferum & 2 & - & - & - & Lymphangioma & - & - & - & 4 \\
\hline Intradermal Naevus & 5 & 4 & - & - & Trichoepithelioma & 2 & - & - & - \\
\hline Inverted Papilloma & 1 & - & - & - & Sebaceous Adenoma & 1 & - & - & - \\
\hline Pilomatricoma & 5 & 4 & - & - & $\begin{array}{l}\text { Sebaceous Gland } \\
\text { Hyperplasia }\end{array}$ & 1 & - & - & - \\
\hline Seborrheic Keratosis & 9 & 3 & 2 & - & Squamous Papilloma & 2 & 1 & - & 6 \\
\hline Wart & 9 & 1 & 5 & - & Steatocystoma & 1 & - & - & - \\
\hline Teratoma & 1 & - & - & - & Molluscum Contagiosum & - & 1 & 1 & - \\
\hline Trichofolliculoma & 1 & - & - & - & $\begin{array}{c}\text { Proliferating Trichilemmal } \\
\text { Cyst }\end{array}$ & - & 5 & - & - \\
\hline & & istr & $0 \pi$ & iffer & nt Types of Tumours of Skin & & & & \\
\hline
\end{tabular}

\section{DISCUSSION}

Skin cancer is one of the oldest cancers known to man. The earliest accredited report of skin cancer is found in the 5th
Century BC in the writings of Hippocrates. The earliest incidence of skin cancer was discovered by paleopathologists in the skin of Peruvian mummies in 4th Century BC.(11) 
Here, total 312 patients of benign and malignant skin lesions were studied from year 2014 to year 2017. According to our study the highest incidence of skin cancer was in the age group 41-50 years and $>51$ years. Jina et al in their study also found that skin lesion were most common in 5th to 7 th decade of life followed by the 4th decade. The lowest occurrence of skin cancer according to their study was 2 nd decennium and below.(9) Ivan et al also found similar results. In their study higher incidences on skin tumour were in age group 31-40 years and 41-50 years.(12)

In our study males outnumbered females, Jina et also found similar results in their results. In their study male to female ratio was 1.9:1.(9) In a consecutive study of four years we found that there were more patients from rural background as compared to urban. Similar results were also present in a study carried out by Kumar et al. In their study $76 \%$ patients from rural population as compared to urban population.(13) In our study swelling were the most common clinical feature followed by papule, pigmented lesions, cyst and ulcer.

In our study squamous cell carcinoma was most common followed by basal cell carcinoma. In study by Jina et al SCC is commoner than BCC. Out of 101 patients, 68 (67.33\%) had SCC and 21 (20.79\%) had BCC followed by 10 (9.90\%) cases of MM. A similar study done by Godbole VK and Toparani HT in 1968 and by NCRP data (1990-96) confirmed the same. $(14,15)$ But in contrast to this, studies done by Marks $\mathrm{R}$ and Bernsten SC, Limkk and Heidelberg KA, SCC is the second most common skin cancer after BCC (clinical features). Increased exposure to sunlight is one of most important risk factors for development of skin cancer. The risk of developing MM after exposure to sunlight is increased and was accessed in a study by Osterlind A et al in a Danish case control study. Similar finding was confirmed in a study by Elwood JM et al.(16-18) Similarly, the pathogenesis of BCC most commonly involves exposure to ultraviolet light (UVL), particularly rays in the UVB spectrum (290 to $320 \mathrm{~nm}$ ), as confirmed in a study by Leffell DJ.(19) Factors involved in the pathogenesis of SCC are similar to those for BCC and include exposure to UVL, genetic mutations, immunosuppression, and viral infection.(20-24)

\section{CONCLUSION}

Skin lesions that are suspected to be malignant impose an increasing burden on primary healthcare and most likely on healthcare costs as well. Especially, as many of these lesions are either excised or referred to secondary healthcare. General practitioners should therefore be trained in diagnosing these lesions, as a high diagnostic accuracy can save lives in the case of melanoma. Additionally, it may also prevent unnecessary, costly, excisions and referrals to secondary healthcare.

\section{REFERENCES}

[1] Hermann P, Mehregan AH. Normal structure of skin. In: Hermann P, edr. A Guide to dermatohistopathology. $3^{\text {rd }}$ edn. NewYork: Appleton-Century-Crofts 1981: p. 538.

[2] Luba MC, Bangs SA, Mohler AM, et al. Common benign skin tumours. Am Fam Physician 2003;67(4):729-38.

[3] Flohil SC, de Vries E, Neumann HA, et al. Incidence, prevalence and future trends of primary basal cell carcinoma in the Netherlands. Acta Derm Venereol 2011;91(1):24-30.

[4] Holterhues C, Vries E, Louwman MW, et al. Incidence and trends of cutaneous malignancies in the Netherlands, 1989-2005. J Invest Dermatol 2010;130(7):1807-12.

[5] What are the survival rates for melanoma skin cancer by stage? http://www.cancer.org/cancer/skincancermelanoma/detailedguide/melanoma-skin-cancersurvival-rates. Accessed 07/12, 2013.

[6] Krol AD, Van der Rhee HJ, Dieleman M, et al. The 'freckle bus' campaign: an unhealthy phenomenon or a sensible experiment? Ned Tijdschr Geneeskd 1990;134(42):2047-50.

[7] Chen SC, Bravata DM, Weil E, et al. A comparison of dermatologists' and primary care physicians' accuracy in diagnosing melanoma: a systematic review. Arch Dermatol 2001;137(12):1627-34.

[8] Rogers HW, Weinstock MA, Feldman SR, et al. Incidence estimates of non-melanoma skin cancer (Keratinocyte Carcinomas) in the U.S. population, 2012. JAMA Dermatol 2015;151(10):1081-6.

[9] Jina A, Singh V, Saini S, et al. Clinicopathological profile, diagnosis and treatment of skin cancers at a tertiary care center: a retrospective study. Int Surg J 2017;4(8):2549-55.

[10] Deo SV, Hazarika S, Shukla NK, et al. Surgical management of skin cancers: experience from a regional cancer centre in North India. Indian J Cancer 2005;42(3):145-50.

[11] Rosai J. Tumours and tumourlike conditions of skin. In: Rosai J, eds. Rosai and Ackerman's Surgical pathology. $9^{\text {th }}$ edn. Mosby: An Imprint of Elsevier 2004: p. 130-245.

[12] Ivan RA, Shameema S, Sarada V. Incidence of various soft tissue tumours among benign and malignant cases. European Journal of Experimental Biology 2015;5(3):34-8.

[13] Kumar A, Shrestha PR, Pun J, et al. Profile of skin biopsies and patterns of skin cancer in a tertiary care center of Western Nepal. Asian Pac J Cancer Prev 2015;16(8):3403-6.

[14] Godbole VK, Toprani HT, Shah HH. Skin cancers in Saurashtra. Ind J Pathol Bacteriol 1968;11(3):183-9.

[15] National Cancer Registry Programme, Indian Council of Medical Research. Consolidated report of the population based cancer registries, 1990-96.

[16] Elwood JM, Gallagher RP, Hill GB, et al. Cutaneous melanoma in relation to intermittent and constant sun exposure: the Western Canada Melanoma Study. Int J Cancer 1985;35(4):427-33.

[17] Osterlind A, Tucker MA, Stone BJ, et al. The Danish case-control study of cutaneous malignant melanoma. II. Importance of UV-light-exposure. Int J Cancer 1988;42(3):319-24.

[18] Armstrong BK, Kricker A. How much melanoma is caused by sun exposure? Melanoma Res 1993;3(6):395-401.

[19] Leffell DJ, Brash DE. Sunlight and skin cancer. Sci Am 1996;275(1):52-3, 56-9. 


\section{Jemds.com}

[20] Brash DE, Ziegler A, Jonason AS, et al. Sunlight and sunburn in human skin cancer: p53, apoptosis and tumour promotion. J Investig Dermatol Symp Proc 1996;1(2):136-42.

[21] Brash DE, Ponten J. Skin precancer. Cancer Surv 1998;32:69-113.

[22] Wong SS, Tan KC, Goh CL. Cutaneous manifestations of chronic arsenicism: review of seventeen cases. J Am Acad Dermatol 1998;38(2 Pt 1):179-85.

\section{Original Research Article}

[23] Montagnino G, Lorca E, Tarantino A, et al. Cancer incidence in 854 kidney transplant recipients from a single institution: comparison with normal population and with patients under dialytic treatment. Clin Transplant 1996;10(5):461-9.

[24] Eliezri YD, Silverstein SJ, Nuovo GJ. Occurrence of human papillomavirus type 16 DNA in cutaneous squamous and basal cell neoplasms. J Am Acad Dermatol 1990;23(5 Pt 1):836-42. 